\title{
MEMORY AND NOSTALGIA: PRE-REFORM RUSSIA IN THE MINDS OF THE RUSSIAN NOBILITY OF THE SECOND HALF OF THE $19^{\mathrm{TH}}$ CENTURY
}

\begin{abstract}
This article is devoted to the study of the perception of the pre-reform era by the upper class in the second half of the 19th century, after several years thereof, then decades after the abolition of serfdom. Initial assessments of the peasant reform carried out among the nobility were quite contradictory. They ranged from total rejection and denial to approval of government policies. But all in all, the abolition of serfdom was a turning point in history. The post-reform period of "impoverishment" of the Russian nobility is associated with a rethinking of the place and role of the upper class in society and the state. Not all landowners managed to adapt to the conditions of the post-reform village, they left for the capital, abroad. The diminution of privileges and the loss of the exclusive status of the upper class fueled the mood of nostalgia. The article uses the concept of nostalgia, developed by Svetlana Boym, which provides for the identification of two types of nostalgia: restorative and reflective. Restorative nostalgia manifested itself not only in the collective consciousness of the upper class but became one of the motivations of the conservative policy of Alexander III. Reflective nostalgia was expressed in the growing interest in the study of the culture of noble manors, determined the identity of the upper estate. Overall, it can be argued that nostalgia has become not only an important feature of the collective consciousness of the nobility, but influenced state policy, shaped the image of the future based on the lost past.
\end{abstract}

Keywords: Russian nobility; abolition of serfdom; restorative nostalgia; reflective nostalgia.

Nostalgia, when it ceases to be a feeling of a single individual, opposing the vicissitudes of fate, longing for a distant home, located in space or in time, and

\footnotetext{
* D. Mendeleev University of Chemical Technology of Moscow; Russia.
} 
becomes a phenomenon of social consciousness provokes the scientific interest of historians, sociologists, and culture researchers. Since the beginning of the 21st century, research devoted to nostalgia has become one of the most fruitful areas in mainstream memory studies. It is noteworthy that the leading role in the development of this theme was played by the philologist, specialist in cultural studies and anthropologist Svetlana Boym, who emigrated from the USSR to the USA in 1981. Her focus on the study of nostalgia was largely driven by personal experience and related to the era of the collapse of the Soviet system, coupled with the fall of the Berlin Wall. The subject of her research was both the phenomenon of nostalgia itself and its manifestations in societies of very recent times. She believed that nostalgia in society plays the role of a defensive reaction to the turning points of history.

A significant number of works by Russian and foreign sociologists and specialists in cultural studies are devoted to nostalgia for the Soviet past (Bartmanski 2011; Kasamara, Sorokina 2011; Zborovskij, Shirokova 2001). Its authors were attracted by the phenomenon of social consciousness, which manifested itself quite clearly and reflected the reaction of society to large-scale changes in the last decades of the 20th century.

In the process of its historical development, and especially in the 19th 20th centuries, Russia has gone through more than one crucial era, marked by the breakdown of social and economic structures, a break with tradition and cultural codes of the past. Not all contemporaries of these events managed to successfully adapt to the changes. A person who has fallen into the flywheel of history inherent with a sense of loss of direction and, as a result, longing for the past. The larger the changes, the more they affect the destinies of various social strata, the more clearly this feeling of loss is manifested in society. Therefore, it is not at all surprising that nostalgia has left a very distinct mark in the history of Russia. Many Russian literary works have a touch of nostalgia, which sometimes becomes the main theme, and sometimes acts as a background for the development of the plot. At the same time, there are practically no historical studies devoted to comprehension of nostalgia in the context of the events of the 19th - early 20th centuries in Russia.

This article is devoted to the analysis of how nostalgia for the pre-reform era arose among the upper class of the Russian Empire in the decades following the abolition of serfdom, and how it gradually became a significant factor that influenced domestic politics, and therefore, indirectly determined the image of 
the future.

Nostalgia in Russia as a mass phenomenon of public consciousness initially appears in the second half of the 19th century as an emotionally colored memory of the pre-reform past. The most iconic artistic embodiment of this nostalgia was the play by A. Chekhov The Cherry Orchard. "In a broader sense, nostalgia is a rebellion against the modern idea of time, the time of history and progress" (Boym 7-8). It was nostalgia for an era that had gone forever, the features of which were increasingly idealized over time. To a large extent, it was socially colored, inherent to the nobility, and its very existence speaks volumes about the rejection of the post-reform era by numerous representatives of the upper estate, their desire to hide from an alien hostile nowadays in a cozy world of the past. It seemed to many of them that Russia in 1861, obeying the spirit of the times, made an irreparable step. After February 19, 1861, no one openly spoke about their sympathies for serfdom. But the image of the pre-reform village, in which the landlords and their peasants lived in patriarchal harmony, and the landowners' estates flourished, had been increasingly idealized.

The inability of a significant mass of the nobility to come to terms with the complicated living conditions in the countryside after the abolition of serfdom, a clash with the real attitude of the peasantry, which many of them saw only in the process of implementing the peasant reform, forced them to hastily leave their estates. This movement is confirmed by statistics. Many landowners, unwilling to adapt to the new economic conditions, left the countryside, trying to shift the care of their estates onto their estate managers. Some of them sold their patrimonies. They either went abroad, or moved to live in St. Petersburg, enrolled in the local noble society.

However, in the first years after the abolition of serfdom, the feeling of nostalgia as a widespread phenomenon of collective consciousness did not yet emerge. Noteworthy is the thought of Count S. D. Sheremetev that people of the sixties of the XIX century, especially those who themselves "made history", were not inclined to be interested in the events of the past. They were interested in the actual everyday life, and the specialists were to deal with rethinking of history (Sheremetev 156). And this is not surprising, because the comprehension of large-scale transformations, their correlation with the coordinate system of world history always takes time to think. In Russia, most contemporaries assessed the entire era of reforms in the 60-70s of the XIX century as a turning point, unprecedented in scale of transformation, but not all were in a hurry to draw 
conclusions, leaving the time itself to make a verdict. Surely, already in the first post-reform years it became clear that the past could not be returned, but the feeling of loss had not yet become so strong, because it seemed that very little time had passed, and all the participants of the events were still alive. Meanwhile, after the abolition of serfdom in the state, and especially in the countryside, there were too striking changes to be overlooked.

However, there were individual originals who tried to pretend that nothing had happened. The memoirist V. A. Shompulev talks about the Saratov landowner Elena Andreevna Ivanova, a smart and wealthy, generous philanthropist, a visit to whose house was considered almost mandatory for every nobleman who came to the province. In the 1850s, her receptions were compared to those of the tzar household. But after February 19, 1861, although she felt a decrease in income from her estates, E. A. Ivanova could not get used to the new situation and continued to live in the old way, surrounded by a large staff of servants, including a house secretary, a family doctor, and a treasurer. Until her death, she did not mention the name of Emperor Alexander II, and in her presence, no one dared to talk about February 19. After her death, it turned out that she had spent all her fortune, and if she had stayed alive for another month, then neither she nor her servants would simply have nothing to eat (Shompulev 133-4). Denial of the changes that have taken place becomes a breeding ground for nascent nostalgia. As A. Huyssen wrote: "Nostalgia counteracts, even undermines linear notions of progress, whether they are framed dialectically as philosophy of history or sociologically and economically as modernization" (Present Pasts 3).

Undoubtedly, nostalgia, as a retrograde idealization of pre-reform Russia, arose as an emotional reaction to the abolition of serfdom and subsequent transformations. Its emergence is closely related to the image in the collective consciousness of the Russian nobility of that turning point in the history of the 19th century, which became February 19, 1861.

The activities of the publicist M.N. Katkov became a kind of symbol of the first decades of the post-reform era. He was universally recognized as a supporter of state conservatism at the time of reforms. M. N. Katkov in his speeches tried to propagandize protective principles, warning against too hasty reforms, calling for an orientation towards already established institutions, continuing to view the Russian nobility as the main support of the throne, as opposed to the growing bureaucracy. 
The Slavophiles played a rather noticeable role in the society of that time, whose most prominent representatives, such as Prince Cherkassky and Yuri Samarin, members of the Editorial Commissions, had a direct impact on the preparation of the Statutes Concerning Peasants Leaving Serf Dependence. They did not doubt the enormous significance of the emancipation of the peasants in Russia, which they brought closer with all their activities over the previous decades. But, considering the final documents of the peasant reform to a certain extent the fruits of their activities and seeing the embodiment of their ideas in practice, they could not be completely satisfied with what they had done. Already in March 1861, Samarin wrote: "When faced with reality, all the shortcomings of the Statutes hurt the eyes ... I sometimes involuntarily come to horror. Who will understand, who will interpret it?" (Trubeckaja 280-1)

Chicherin's memoirs reflect his high appraisal of the peasant reform. At the same time, he has recorded rather obvious dissatisfaction with the supreme power and disbelief in its capabilities in the society during the first post-reform months of 1861. He quotes the text of a letter from his brother Vasily, who reported from St. Petersburg: "Pessimists, and there are many of them, say that five years will not pass without abdicating the throne, others go much further" (Chicherin 13). Preeminently, it was about the government's reaction to the unrest of students in the two capitals.

Thus, the first and main of the Great Reforms, which served as the beginning of a new era in the history of Russia, became an event in the life of every contemporary, evoked a strong emotional response. This is not surprising, since not only the entire economy of the Russian Empire, but also the lives of most of the people who inhabited it, depended on the fate of the Russian countryside.

In the post-reform period, the living conditions of the landowners underwent much more significant changes than the living conditions of the peasants. Those who really wanted to take care of their household had to give up idle laziness. But the overwhelming majority chose the path of least resistance: absenteeism, property management through estate managers, metayage, unproductive waste of the funds received with pain and misery, and, as a result, the "impoverishment" of the Russian nobility.

During the post-reform decades, many journal articles, and small works on the history of the nobility appeared. They were often polemical in nature. Their authors were worried about the reasons for the "impoverishment" of the nobility, 
the loss of their former role in society. They usually looked for the origins of these negative processes in the past of the upper class, from its inception to the reform of 1861. Speaking from a conservative standpoint, they were extremely negative about the impact of the reforms on the economic and political position of the upper estate. As a positive program of action, they proposed consolidation of the upper estate, strengthening its position in local self-government, preserving, and strengthening the traditional influence of the local nobility on the Russian peasantry (Semenov 1898; Jarmonkin 1895).

All these testimonies and voices from the past not only brighten, revive in all the variety of shades the picture of such a historical event as the abolition of serfdom in Russia. They let us understand how the image of the peasant reform is being formed in the minds of the upper estate. Based on this image, fixed in the collective consciousness, over the years, a collective memory of a historical event as a turning point is formed. In this case, this collective memory develops into nostalgia for the pre-reform village. Using Svetlana Boym's concept of nostalgia, we can describe it as a collective memory of the past with a strong emotional background. "I would define it as a longing for a home that no longer exists or has never existed. Nostalgia is a sentiment of loss and displacement, but it is also a romance with one's own fantasy" (Boym 7-8).

It is precisely this strong feeling that can transfer nostalgia from the realm of the spirit to the realm of practice, and sometimes even real politics. When the nobility in the 70-80s of the XIX century increasingly begins to experience the process of "impoverishment", which has been repeatedly described in the literature, when nostalgia for the pre-reform countryside, for the lost estate becomes the dominant mood in the social milieu of gentry, the conservative trend in domestic politics also intensifies. During the peasant reform, many landowners, having sold their estates, which ceased to serve them as a source of income, went into civil service, that is, they joined the ranks of the bureaucracy. They became the conductors of state policy, but carried in themselves nostalgia for a bygone era, as well as a negative attitude not so much to the abolition of serfdom, but to how it was carried out.

Let us give an example, in his "Notes of a Privy Councilor" N. A. Kachalov, who during his long career was several times elected as marshal of nobility of the Belozersk district of the Novgorod governorate, was the Governor of Arkhangelsk governorate, and then became the director of the Department of Customs Duties, spoke rather sharply about the reforms 60-70 years of the XIX 
century in general and the peasant reform. "The reforms of the previous reign, which were beneficial in their purpose, practically destroyed the nobility and not only did not create an appropriate substitute new class but called to the action of the scum of society. Experience has shown what a huge mistake this is, and to this day, in all branches of government, the best public servants are nobles..." (Kachalov 378)

The era of Great Reforms associated with the reign of Alexander II ended, his son Alexander III came to power. It was at this time that nostalgia for the "glorious past" was established in the minds of the upper class. It is possible with a high degree of probability to link his conservative policy itself, which was proceeding from the patriarchal model of Russia, with an attempt to reconstruct the lost ideal. Svetlana Boym called this version of nostalgia restorative nostalgia aimed at returning to the roots (Boym 13). It is likely that the concrete political decisions of the Russian government did not have a clearly formed goal - to neutralize the consequences of the reforms of the previous reign and, thus, to correct the committed historical mistake. Leontovich V.V., one of the prominent historians and jurists of the Russian diaspora, wrote that in the eighties of the XIX century, no one, even the most consistent reactionaries, thought about the restoration of serfdom and the institutions associated with it (Leontovich 333). At the same time, strong nostalgia for a bygone era formed the picture of the future inherent in the authorities, determined its conservative political program. "The fantasies of the past determined by the needs of the present have a direct impact on the realities of the future" (Boym 7-8). The conservatives denied the reforms of the 60-70s, but they could not work out a general positive program of action.

Adoption of the Land Captain Statute in 1889, correcting the Zemstvo reform of 1864, demonstrates the fact that restorative nostalgia could well dictate the political agenda. The purpose of this law was to strengthen local power at the expense of the noble landowners, whom the government still regarded as conductors of its influence, ensuring their control over the zemstvos, and especially over the peasant world. Only representatives of the nobility who owned real estate in a given area could be appointed to the post of a land captain. In this case, the advantage was given to persons who served as marshal of nobility, who did not even have to possess the property qualification required of others. This law was initiated by count D. A. Tolstoy, an "ultra-conservative", as Yuri Witte called him, and was actively supported by Prince Meshchersky, the publisher of the newspaper "Grazhdanin". The implementation of The Land 
University of Bucharest Review $\propto$ Vol. X/2020, no. 1 (new series)

Re-writing, Re-imagining the Past (I)

Captain Statute came at a time when D. A. Tolstoy as Minister of Internal Affairs was replaced by I. N. Durnovo, in the recent past the Marshal of Nobility of the Yekaterinoslav governorate.

When the draft of The Land Captain Statute was discussed in power circles, many opposed it, including K.P. Pobedonostsev. Nevertheless, Alexander III signed it, tempted by the thought that "all of Russia would be divided into zemstvo plots, that at each plot there would be a respected nobleman who was universally respected in the district, that this respectable noble landowner would take care of the peasants, he would judge them and arrange them" (Vitte 299).

In his memoirs, the prominent statesman Witte first noted as the main drawback of this law the lack of the principle of separation of judicial and administrative powers. He pointed out that, in practice "this idyll of a noble landowner" turned out to be an illusion. Land captains did not play the role of independent arbitrators, but were built into the structure of the local administration. With a few exceptions, these were "retired officers, cadets, noblemen who did not graduate from higher educational institutions, in a word, persons of the most second-rate class" (Vitte 300).

Witte considered it necessary to abolish the institution of land captains and equalize the peasantry in civil rights with other estates, even if this destroyed the conservative patriarchal illusion. Assessing the introduction of this institution, he took the position of an outside observer, a representative of the top administration, in accordance with his own ideas about the direction in which Russia should develop. So, for example, he writes about the impossibility for a cultured state to deny the need for the practical application of the principle of separation of powers, which demonstrates his adherence to the canonical doctrine of modern times.

From the point of view of the old landowner V. A. Shompulev, who in 1891 took over the post of the land captain in the Saratov governorate, this institution, on the contrary, was necessary and effective. In 1891 he was 61 years old. He began his service in the time of Emperor Nicholas I, and, having retired, was repeatedly elected to the post of marshal of nobility of the Saratov governorate, an honorary justice of peace. At the time when The Land Captain Statute was being adopted, he was in St. Petersburg. "It will be interesting to recall this time, when not only the press, but also many of the dignitaries in the capital were far from sympathizing with this reform, but the unyielding will of the wise Emperor put an end to any opposition in this case. ..." (Shompulev 188) 
Shompulev took an active part in carrying out the peasant reform in the Saratov governorate, he was aware of the real situation in the countryside. He believed that after the end of the activities of conciliators, the peasants, left to themselves, were mired in immoral behaviour (Shompulev 190). For him, who had absorbed from a young age the idea of the importance of the caring attitude of the landowners to the peasants, which formed the basis of the patriarchal model of social relations in the countryside, the introduction of the position of land captain was the most natural thing. We can say that Shompulev was a connecting link between the bygone pre-reform era and the time when the restorative nostalgia begins to increasingly determine the domestic policy of Russia. But the peculiarity of the figure of the old landowner was also that he was a living embodiment of tradition.

The post-reform village, which he had to deal with thirty years after the Manifesto of February 19, retaining many features of a traditional society, archaism, deep ignorance, and prejudice, was not inclined to bow before the authority of the landowner endowed with administrative power of a land captain. Here the authority of age and seniority was rather at work. Shompulev gives more than one evidence, in his memoirs, when respect for his age among the peasants forced them to listen to his arguments. For example, when a drunken peasant and his wife, who stood up for him, almost staged a mass slaughter, the "old man's authority" of Viktor Antonovich stopped the enraged crowd of peasants. Sometimes he was called by the people: "grandsir-chief". Moreover, the author of the memoirs emphasizes the second word, but in his own retelling of various episodes of his service as a land captain, the first word is repeated more often and persistently. All this is very different from the system of relationships between landlords and peasants in the time of serfdom. Then the authority of the landowner, who possessed patrimonial power in relation to the peasants, was much higher, regardless of his age. The peasant microcosm reflected the macrocosm, where the Tsar was the vicar of God on earth, and the landlord played the main role in the village. "After all, in the old days it was not what it is now. Everyone knew that no matter what the barin was, but all the same, the barin was appointed by God, and you must love him" (Tolychova 118). The landowner in the eyes of the peasant world was a master, a tax collector, a judge. But also, a father, an agronomic advisor, a deliverer from hunger.

Therefore, those relations between the land captain and the peasants which V.A. Shompulev describes in his memoirs suggest that this institution operated 
already under new conditions, and, by and large, was an example of "invented tradition" of E. Hobsbawm, or one consequence of restorative nostalgia. "'Invented tradition' is taken to mean a set of practices, normally governed by overtly or tacitly accepted rules and of a ritual or symbolic nature, which seek to inculcate certain values and norms of behaviour by repetition, which automatically implies continuity with the past. In fact, where possible, they normally attempt to establish continuity with a suitable historic past" (Hobsbawm 1).

During the reign of Alexander III, the internal policy of the state was aimed at helping the local nobility and was based on patriarchal patronage of the peasantry. The authorities tried to support, and partly to recreate the supposedly existing harmony between these pillars of the throne: the noble class, in whose consciousness the service to the Throne and the Fatherland still occupied a central place, and the peasantry, who relied on the Tsar in every possible way. It may be said that nostalgia, shaping the image of the future based on the lost past is one of the factors that form a model of development like a historical pendulum, from which Russia isn't able to get out for centuries. Epochs of reforms lead to radical changes, which arouses nostalgia for the disappeared past in a large mass of people, which serves as an incentive for subsequent counterreforms. Thus, nostalgia is associated not only with the emotionally experienced past, but is aimed at constructing the future.

The second type of nostalgia that Svetlana Boym describes is reflective nostalgia, for which the awareness of the impossibility of returning to the past and the experience of the fragility of being is inherent. Attention to a bygone era is associated with its aestheticization, and the personal level of experienced nostalgia does not cancel its existence at the level of the phenomenon of collective memory (Boym 15). In the 80s-90s of the XIX century, interest arose in the study of the history of the pre-reform era and estate living. Researches on the genealogy of the Russian nobility appeared. At the turn of the 19th and 20th centuries in Russia there were several historical periodicals, such as "Old Years", "Old Estate", "Russian Archive", "Voice of the Past", etc. The bulk of publications in these journals covered the recent, imperial period in the history of Russia, and much less often touched on the pre-Petrine era. Interest in the artistic culture of pre-reform Russia is reviving. It was at this time that the understanding of the fact that the culture of landowners' estates was an integral part of the Russian spiritual heritage took place. Passion for the culture of manors of the XVIII-XIX 
centuries became the work of life of the famous art critic Baron N. N. Wrangel, the younger brother of one of the leaders of the white movement P. N. Wrangel.

After two or three decades after 1861, nostalgia for the pre-reform village is taking shape in the mind and in words. Here is what N.N. Wrangel wrote about a landlord`s Russia that has gone into the past:

All this culture, all this way of life, all this past, so close in time, now every year it seems as if it is removing for several centuries... And therefore, perhaps, the old story about grandfathers and grandmothers, about Arabs and serfs, about mahogany furniture and about houses with columns on the banks of old ponds tenderly caresses and beckons us? (Wrangel 27)

Thus, in the post-reform period, the results of the peasant reform turned out to be both an object of rethinking and an object of emotional experience, deep feeling among the upper class. In relation to them, during the second half of the nineteenth century, an image of reforms was formed in the collective memory of the nobility, and it was they who became the basis for constructing a "lost past" that became a breeding ground for nostalgia for the blessed times "before the catastrophe".

Nostalgia for pre-reform Russia manifests itself in the collective consciousness of the upper class in the second half of the 19th century, or rather in its last two or three decades, simultaneously in two types: restorative and reflexive. The conservative trend in the politics of Alexander III can also be partly related to the experience of the practical implementation of restorative nostalgia. But in the 20th century, the first type of nostalgia for pre-reform Russia is gradually being squeezed out of public consciousness, while reflective nostalgia continues to excite the minds and feelings of the Russian nobility. Many of them lost their estates, some of them went bankrupt, but nostalgia helped them maintain their social identity in the new century.

We can add that shortly after the collapse of the Russian Empire, the Russian nobility will again be seized by nostalgia, which, unlike the previous one (temporal), acquires more and more distinct spatial features, associated with the first wave of emigration. The study of the nostalgia of the "Russian exodus" may become the topic of an interesting new research. 


\section{Works Cited}

Bartmanski, Dominik. "Successful icons of failed time: Rethinking postcommunist nostalgia." Acta sociologica, vol. 54, no. 3, 2011: 213-31.

Boym, Svetlana. "Nostalgia and its discontents." The Hedgehog Review, vol. 9, no. 2, summer 2007: 7-8.

Chicherin, Boris. N. Vospominanija. v.2, Sabashnikovyh pub., 2010.

Hobsbaum, Eric, Ranger, Terence. The invention of tradition. Cambridge University Press, 2013.

Huyssen, Andreas. Present Pasts: Urban Palimpsests and the Politics of Memory. Stanford University Press, 2003.

Jarmonkin, Valentin V. Zadacha dvorjanstva. Tipografija M. P. S. (tovarishhestva I. N. Kushnerev i $\mathrm{K}^{\circ}$ ), 1895.

Kachalov, Nikolaj A. Zapiski tajnogo sovetnika. Novyj hronograf pub., 2012.

Kasamara Valerija. A., Sorokina Anna A. "Postsovetskaja nostal'gija v povsednevnom diskurse rossijan." Obshhestvennye nauki $i$ sovremennost', no 6, 2011: 18-32.

Leontovich, Viktor V. Istorija liberalizma v Rossii. 1762-1914. Russkij put' pub., 1995.

Sheremetev, Sergej D. Memuary. vol. 1, Indrik pub., 2004.

Semenov, Nikolaj P. Nashe dvorjanstvo. Gosudarstvennaja tipografija, 1898.

Shompulev, Viktor A. Zapiski starogo pomeshhika. Novoe literaturnoe obozrenie pub., 2012.

Tolychova, Tat'jana. Semejnye zapiski. Tipografija Bahmeteva, 1865.

Trubeckaja, Ol'ga. Knjaz' V. A. Cherkasskij i ego uchastie v razreshenii krest'janskogo voprosa: Materialy dlja biografii. vol. 1, Tipografija Lissnera i Geshelja, 1901.

Vitte, Sergej Ju. Vospominanija. vol. 1, Izdatel'stvo social'no-jekonomicheskoj literatury, 1960.

Vrangel' , Nikolaj N. Pomeshhich'ja Rossija. Publishing House Kolo, 2007.

Zborovskij, Garold E., Shirokova, Elizaveta A. "Social'naja nostal'gija: k issledovanijam fenomena." Sociologicheskie issledovanija, no. 8, 2001: 31-34. 